WE investigated the effect of the excitatory amino acid (EAA) receptor agonists L-glutamate, $\boldsymbol{N}$-methylD-aspartate (NMDA), (RS)-a-am ino-3-hydroxy5-methyl-4-isoxazole propionic acid (AMPA) and kainic acid on $\mathrm{KCl}$-induced contractions of rabbit tracheal smooth muscle, as well as the role of epithelium and endogenously produced nitric oxide and prostaglandins on these responses. L-Glutamate decreased KCl-induced contractions up to $30 \%$. This effect was attenuated by epithelium removal, tetrodotoxin, methylene blue and indomethacin but not by $\boldsymbol{N}^{\mathrm{G}}$-nitro-L-arginine methyl ester. While NMDA, AMPA and kainic acid had no effect, the combination of NMDA + kainic acid decreased KCl-induced contractions. These results suggest that, in rabbit trachea, L-glutamate has, at least in part, an epitheliumdependent effect mediated via prostaglandin formation and that the EAA receptors involved are nonclassical.

Key words: Airway smooth muscle, Rabbit, L-Glutamate, Prostaglandins, EAA receptors

\section{Epithelium-dependent effect of L-glutamate on airways: involvement of prostaglandins}

\author{
Apostolia A. Hatziefthimiou ${ }^{\text {CA }}$, Konstantinos \\ I. Gourgoulianis and Paschalis-Adam Molyvdas
}

Department of Physiology, Medical School, University of Thessaly, Papakiriazi 22, 41222 Larissa, Greece

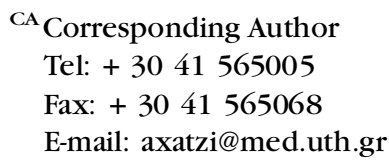

\section{Introduction}

In humans, glutamate (in the form of monosodium) could be a provoking factor involved in asthma attacks, although the existence of monosodium glutamate-induced asthma has not been established. ${ }^{1}$ Data obtained from animal studies support the hypothesis that the intense exposure to glutamate can be toxic for lungs because the over-activation of excitatory amino acid (EAA) receptors, mainly of the $N$-methylD-aspartate (NMDA) type, is involved in the pathogenesis of a variety of lung lesions like acute injury, ${ }^{2}$ pulmonary edema, ${ }^{3}$ oxidant tissue injury, ${ }^{4}$ airway hyper-responsiveness and inflammation. ${ }^{5,6}$ In animal lungs, accumulating data suggest that the localization of EAA receptors are presumably neuronal and L-glutamate exerts its effect via $\mathrm{NMDA}^{2,3}$ or via nonclassical EAA receptors. ${ }^{7}$

The purpose of the present study was first to investigate the effect of main ionotropic EAA receptors agonists such as L-glutamate, NMDA, (RS)a-amino-3-hydroxy-5-methyl-4-isoxazole propionic acid (AMPA) and kainic acid on $\mathrm{KCl}$-induced contractions of rabbit tracheal smooth muscle. Second, we examined the involvement of epithelium and the endogenous formation of nitric oxide (NO) and prostaglandins in the effect of L-glutamate.

\section{Materials and methods}

Adult rabbits (1-2 kg body weight) of either sex were sacrificed by an overdose of intravenously administered sodium thiopentone (Abbot, Italy). Exothoracic tracheal tissue was removed and placed in Krebs solution ( $\mathrm{pH} 7.4$ at $37^{\circ} \mathrm{C}$ ) with the following composition: $\mathrm{Na}^{+}, 137 \mathrm{mM} ; \mathrm{Mg}^{2+}, 1.1 \mathrm{mM} ; \mathrm{K}^{+}$, $5.9 \mathrm{mM} ; \mathrm{Cl}^{-}, \quad 123.0 \mathrm{mM} ; \mathrm{Ca}^{2+}, 2 \mathrm{mM} ; \mathrm{H}_{2} \mathrm{PO}_{4}^{-}$, $1.2 \mathrm{mM} ; \mathrm{HCO}_{3}{ }^{-}, 24.9 \mathrm{mM}$; and glucose, $9.6 \mathrm{mM}$. The solution was gassed with $95 \% \quad \mathrm{O}_{2}$ and $5 \%$ $\mathrm{CO}_{2}$.

After the removal of connective tissue, tracheal rings were dissected from tracheas under an SZ30 Olympus stereoscope (Japan). The tracheal strips were $2 \mathrm{~mm}$ in width and were cut longitudinally through the cartilage opposite the smooth muscle layer. In experiments with epithelium-denuded tracheal rings, the epithelial layer was removed with a cotton-tipped applicator. Each strip was placed with the superfused luminal side up in a water-jacketed organ bath. One end of the tracheal strip was fixed on the bottom of the organ bath and the other to the transducer tip. The entire strip was continuously perfused with oxygenated Krebs solution at $37^{\circ} \mathrm{C}$. The volume of the organ bath was approximately $3 \mathrm{ml}$ and the perfusion rate was $5 \mathrm{ml} / \mathrm{min}$. Tracheal strips were stretched manually to $1 \mathrm{~g}$ resting tension and were allowed to equilibrate in the organ bath for at least $60 \mathrm{~min}$. Before starting the experiments, the rings were contracted by elevating the extracellular $\left[\mathrm{K}^{+}\right]_{\mathrm{o}}$ concentration to $80 \mathrm{mM}$ or by $10^{-5} \mathrm{M}$ acetylcholine (ACh) until a constant and reproducible contraction was achieved. Elevating potassium solutions were made by isosmotic substitution with $\left[\mathrm{Na}^{+}\right]_{0}$. The concentration of $10^{-5} \mathrm{MACh}$ was chosen 
because, in pilot studies, $10^{-5} \mathrm{M}$ ACh produced $50 \%$ of the maximal response (data not shown). Changes in tension were recorded on a Grass FT03C force displacement transducer (Astro Med Inc., USA) and displayed via a Universal oscillograph (Harvard Apparatus, England) recorder. To investigate the effect of s-glutamate on ACh-induced or KCl-induced contractions, increasing concentrations of s-glutamate (range, $10^{-9}$ to $10^{-3} \mathrm{M}$ ) were added in the perfusion medium and, after $15 \mathrm{~min}$, contractions were induced by $\mathrm{ACh}$ or $\mathrm{KCl}$. The effect of the main ionotropic EAA receptors agonists NMDA, AMPA and kainic acid (range, $10^{-9}$ to $10^{-4} \mathrm{M}$ ) on $\mathrm{KCl}$-induced contractions was studied in the same way. We also studied the effect of kainic acid (range, $10^{-9} \mathrm{M}$ to $10^{-4} \mathrm{M}$ ), in the presence of $10^{-6} \mathrm{M}$ NMDA and the effect of the NMDA (range, $10^{-9} \mathrm{M}$ to $10^{-4} \mathrm{M}$ ) in the presence of $10^{-6} \mathrm{M}$ kainic acid. The experiments with NMDA were performed in the presence of $\mathrm{Mg}^{2+}$ and also in $\mathrm{Mg}^{2+}$-free Krebs solution.

Experiments with epithelium-intact and epithelium-denuded preparations were carried out in parallel. In experiments in which tetrodotoxin (TTX), methylene blue, $N^{\mathrm{G}}$-nitro-t-arginine methyl ester (L-NAME) and indomethacin were used, the rings were incubated with the inhibitor for $45 \mathrm{~min}$ before the exposure to t-glutamate. Contractions were evoked by $80 \mathrm{mM} \mathrm{KCl}$.

Values are expressed as a percentage of reference contraction induced by $80 \mathrm{mM} \mathrm{KCl}$ or $10^{-5} \mathrm{M} \mathrm{ACh}$. All data are presented as mean \pm standard error (SE), and $N$ refers to the number of animals. Statistical differences between all the responses were assessed using paired or unpaired $t$-tests, and $p<0.05$ was considered to be significant.

ACh, s-glutamate, NMDA, AMPA, kainic acid, TTX, methylene blue, L-NAME and indomethacin were all obtained from Sigma (Germany).

\section{Results}

L-Glutamate evoked a significant concentrationdependent decrease of KCl-induced contractions (Fig. 1). The maximal decrease (30\%) was observed in the presence of $10^{-3} \mathrm{M}$ L-glutamate $(\phi<0.001$, paired $t$-test; Fig. 1). The removal of epithelium, on the contrary, reduced significantly the effect of L-glutamate $(p<0.05$, paired $t$-test; Fig. 1$)$. L-Glutamate had no effect on ACh-induced contractions (Fig. 2). The presence of TTX $\left(3 \times 10^{-6} \mathrm{M}\right)$ in the perfusion medium significantly attenuated the effect of L-glutamate on KCl-induced contractions $(p<0.01$, paired $t$-test, for concentrations of $\mathrm{t}$-glutamate between $10^{-8}$ and $10^{-3} \mathrm{M}$; Fig. 3). The treatment of preparations with methylene blue $\left(10^{-5} \mathrm{M}\right)$ attenuated significantly the effect of L-glutamate on KCl-induced contractions $(p<0.01$, unpaired $t$-test; Fig. 4$)$ and had

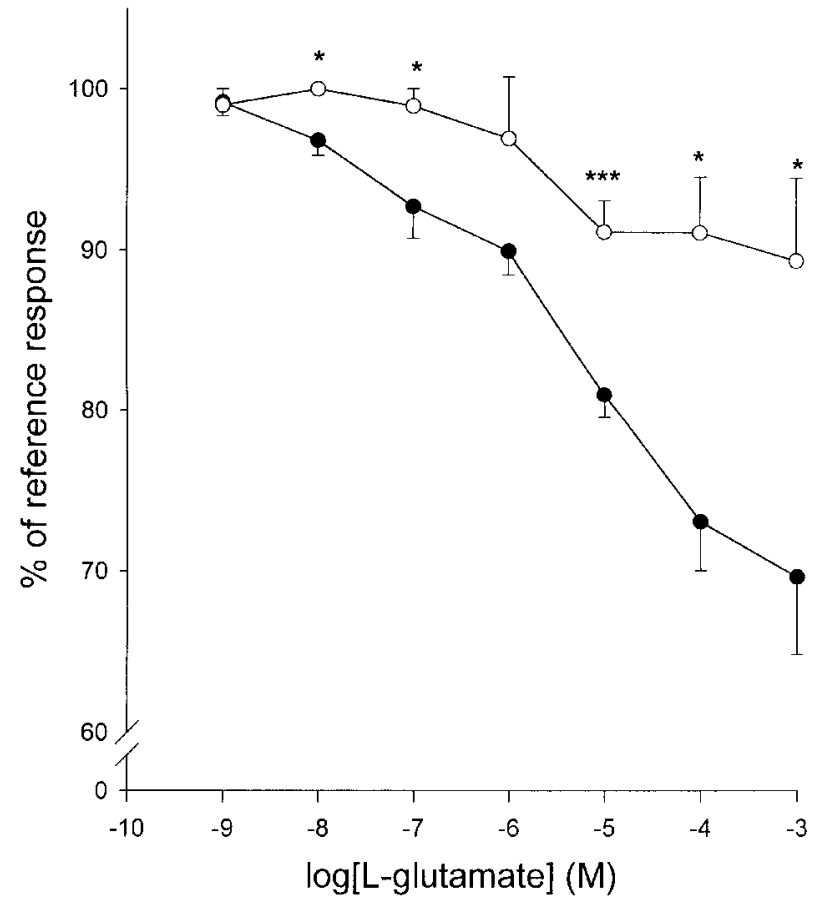

FIG. 1. L-Glutamate effect on epithelium-intact (-) and epithelium-denuded preparations $(\bigcirc)$. The responses are mean \pm SE $(n=5)$ and are plotted as a percentage of the reference response before the exposure to L-glutamate. ${ }^{*} p<$ $0.05,{ }^{* *} p<0.001$, paired $t$-test.

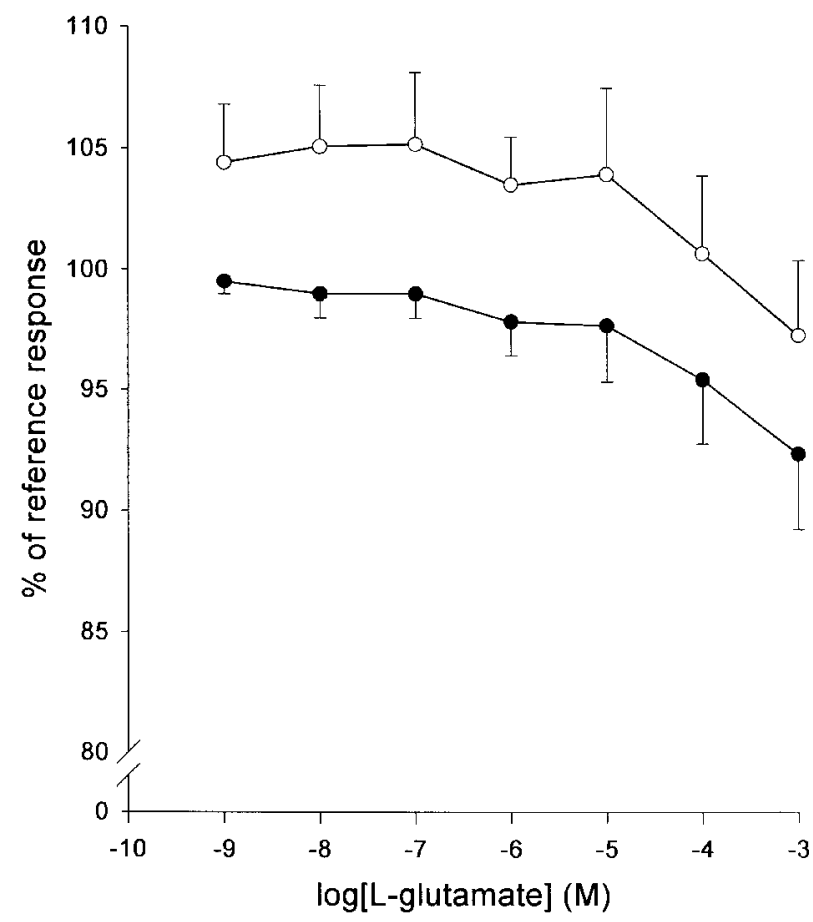

FIG. 2. L-Glutamate effect on ACh-induced contractions (๑), and in the presence of methylene blue $(\bigcirc)$. The responses are mean $\pm \operatorname{SE}(n=6)$ and are plotted as a percentage of the reference response before the exposure to L-glutamate. 


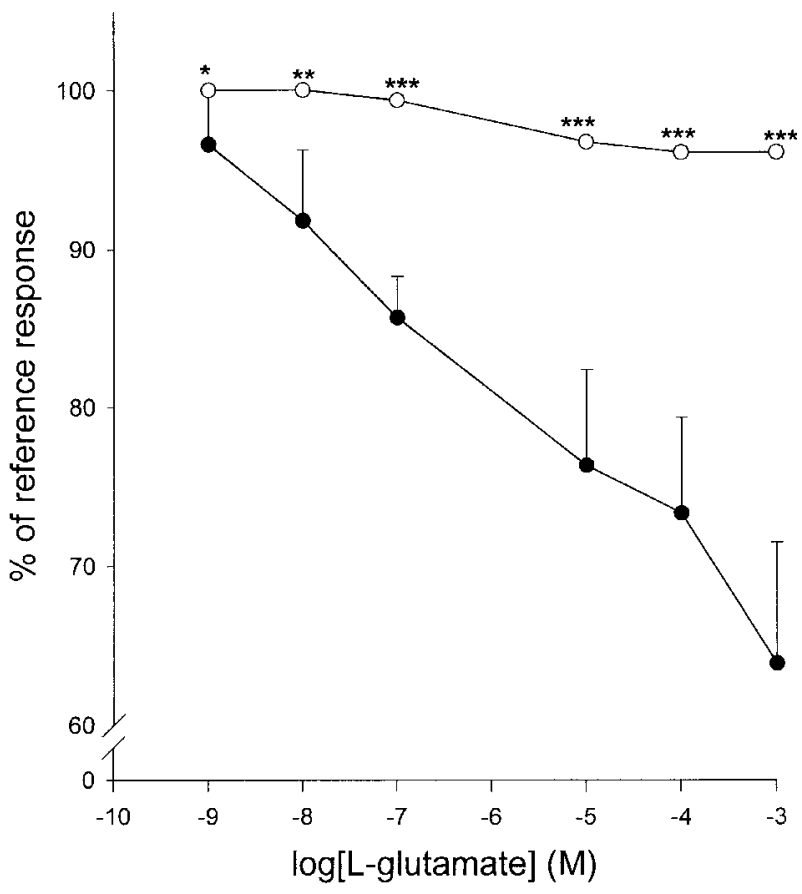

FIG. 3. The effect of L-glutamate on $\mathrm{KCl}$-induced contractions $(\bullet)$, and in the presence of TTX (O). The responses are mean \pm SE $(n=6)$ and are plotted as a percentage of reference response before the exposure to L-glutamate. $p<0.05,{ }^{* *} p<$ $0.01,{ }^{* *} p<0.001$, paired $t$-test.

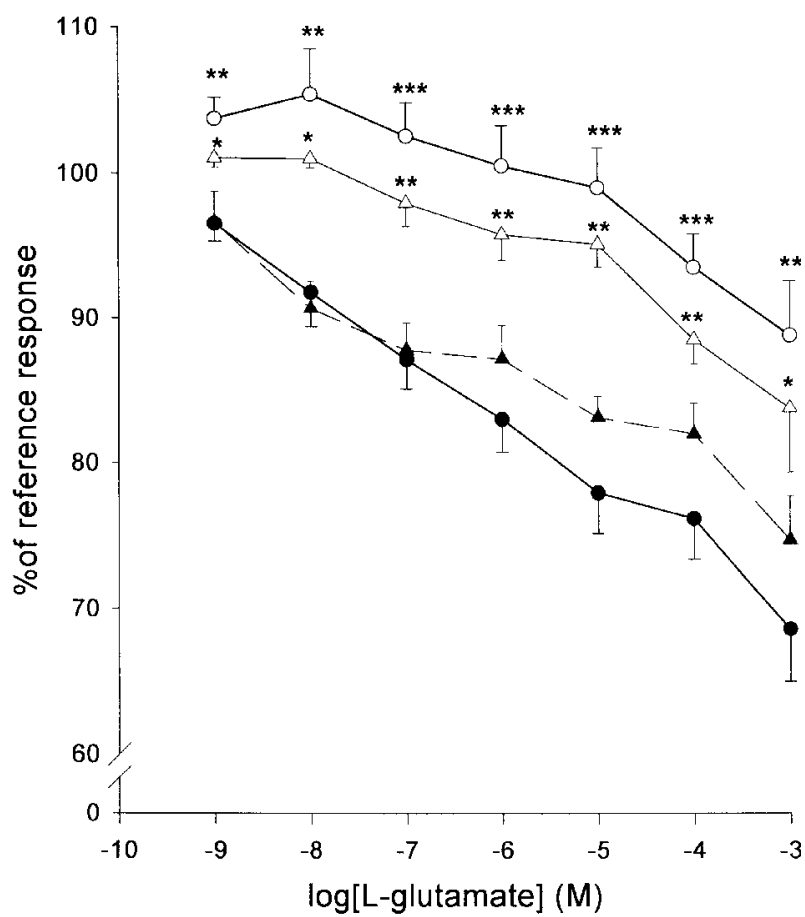

FIG. 4. The effect of L-glutamate on $\mathrm{KCl}$-induced contractions $(\bullet)$, and in the presence of methylene blue $(\bigcirc)$, L-NAME ( $\mathbf{\Delta})$ and indomethacin $(\triangle)$. The responses are mean \pm SE; $n=11$ for experiments with L-glutamate, $n=7$ for experiments in the presence of methylene blue, $n=5$ for experiments in the presence of L-NAME, and $n=6$ for experiments in the presence of indomethacin. The responses are plotted as a percentage of the reference response before the exposure to L-glutamate. ${ }^{*} p<0.05,{ }^{*} p<0.01$ and ${ }^{* * *} p<0.001$, unpaired $t$-test.

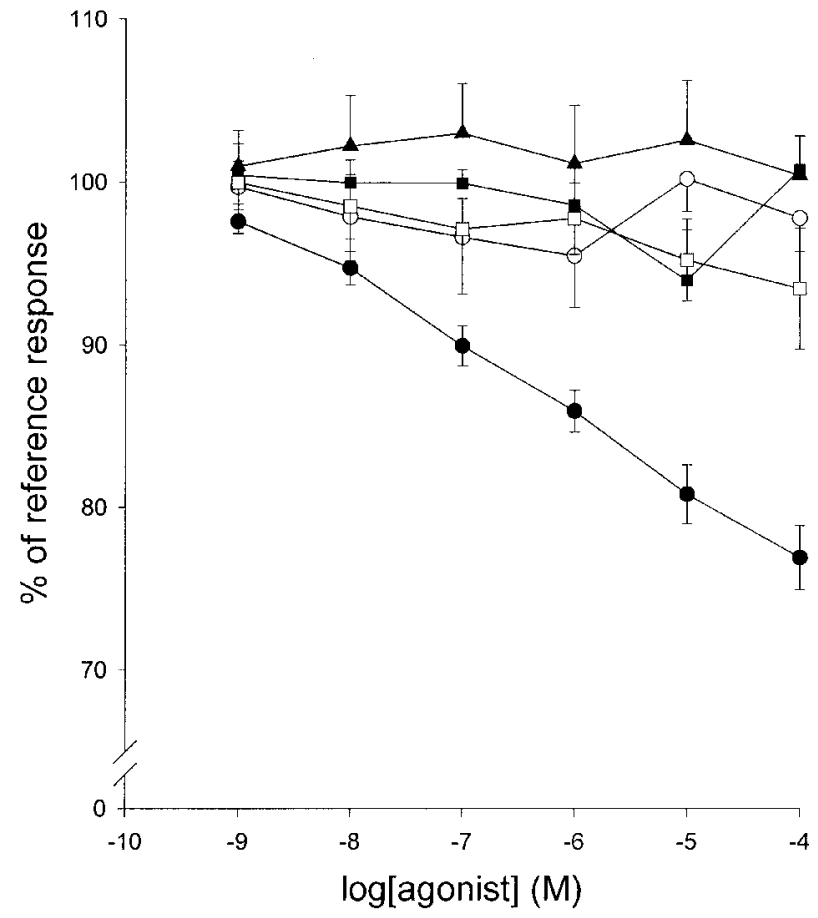

FIG. 5. The effect of L-glutamate ( $)$, AMPA ( $\bigcirc)$, kainic acid $(\square)$, NMDA ( $\square$ ) and NMDA in magnesium-free medium $(\boldsymbol{\Delta})$. The responses are mean $\pm \mathrm{SE} ; n=11$ for L-glutamate, and $n=$ 5 for each other agonist. The responses are plotted as a percentage of the reference response before the exposure to agonist.

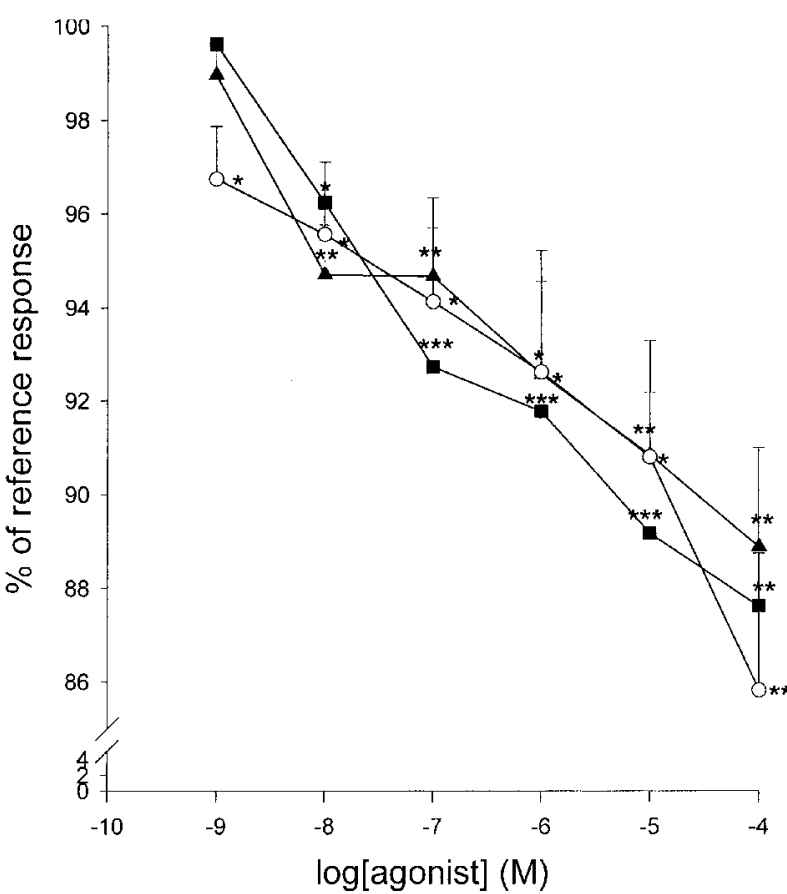

FIG. 6. The effect of NMDA in the presence of $10^{-6} \mathrm{M}$ kainic acid $(\boldsymbol{\Delta})$, of kainic acid in the presence of $10^{-6} \mathrm{M}$ NMDA $(\boldsymbol{\square})$, and in magnesium-free medium $(\bigcirc)$. The responses are mean \pm SE $(n=6)$ and are plotted as a percentage of the reference response before the exposure to agonists. ${ }^{*} p<$ $0.05,{ }^{*} p<0.01,{ }^{* *} p<0.001$ paired $t$-test. 
a small, statistically not significant, potentiating effect on contractions evoked by ACh (Fig. 2). The presence of L-NAME $\left(10^{-4} \mathrm{M}\right)$ in the perfusion medium did not influence the effect of s-glutamate (Fig. 4), while the presence of indomethacin $\left(10^{-5} \mathrm{M}\right)$ significantly reduced the effect of L-glutamate $(p<0.05$, unpaired $t$-test; Fig. 4).

Finally, NMDA, in the presence or absence of $\mathrm{Mg}^{2+}$ in the perfusion medium, AMPA or kainic acid had no effect on KCl-induced contractions (Fig. 5). However, the combination of NMDA + kainic acid (NMDA in the presence of $10^{-6} \mathrm{M}$ kainic acid or kainic acid in the presence of $10^{-6} \mathrm{M}$ NMDA) evoked a significant decrease of $\mathrm{KCl}$-induced contractions (Fig. 6). The absence of $\mathrm{Mg}^{2+}$ from the perfusion medium had no effect on these responses (Fig. 6). The combined effect of the two ionotropic EAA agonists, kainic acid and NMDA, was not as potent as that by i-glutamate alone. I-Glutamate, NMDA, AMPA or kainic acid in concentrations already mentioned had no effect on tracheal strips under resting conditions and in the absence of $\mathrm{KCl}$-induced contractile activity (data not shown).

\section{Discussion}

Our results demonstrate that L-glutamate application on rabbit trachea decreases KCl-induced contractions, without affecting ACh-induced contractions of smooth muscle. $\mathrm{KCl}$ in high concentration induces contractions in rabbit trachea mainly via the $\mathrm{ACh}$ release ${ }^{8}$ therefore, we assume that $\mathrm{L}$-glutamate, at the dose tested, had no post-junctional effect. The effect of L-glutamate on rabbit tracheal smooth muscle was attenuated by the removal of epithelium, as well as by the presence of TTX, methylene blue or indomethacin in the perfusion medium. These data provide evidence, first, for the release of a neuronal agent that mediates the r-glutamate effect and, second, for an epithelium-dependent and prostaglandin-dependent way of action.

In perfused rat lungs, activation of NMDA receptors, in the presence of the NO precursor L-arginine, stimulates cGMP formation and synthesis of $\mathrm{NO}^{2,3} \mathrm{To}$ investigate the involvement of cGMP and/or NO in the relaxant effect of L-glutamate, we treated our preparations with methylene blue, an inhibitor of cGMP formation. While methylene blue significantly reduced the effect of $\mathrm{L}$-glutamate, the treatment of our preparations with L-NAME, an inhibitor of NO synthase, had no effect. These results suggest that NO was not involved in the s-glutamate effect on rabbit trachea. Previous studies reported that methylene blue might exert its effect via a mechanism independent of the inhibition of cGMP formation, and may inhibit the synthesis and/or the release of prostanoids. ${ }^{9-11}$ For this reason, we treated our prepara- tions with indomethacin, an inhibitor of cyclooxygenase. The presence of indomethacin in the perfusion medium attenuated the effect of L-glutamate, thus suggesting that L-glutamate exerts its effect, at least in part, via prostaglandin formation.

Although our results provide evidence for a neuronal localization of t-glutamate receptors, their possible site of localization is not clear. L-Glutamate receptor subunits are present on airways. ${ }^{12,13}$ According to the available data, the s-glutamate receptors, mainly of NMDA type,${ }^{14}$ are located on parasympathetic nerves. ${ }^{15}$ In guinea pigs, indirect evidence also support the existence of -glutamate receptors on airways sensory neurons, where they mediate the acute response to capsaicin. ${ }^{5}$ Thus, in rat bronchi, activation of glutamate receptors enhances cholinergic contractions. ${ }^{7}$ This effect may be mediated indirectly by the release of sensory peptides, because sensory peptides may facilitate cholinergic neurotransmission in airways. ${ }^{16-18}$

In contrast to these previous observations, our findings demonstrate a relaxant effect of s-glutamate in rabbit trachea. The discrepancy may be due to species and/or tissue differences. Supporting this, L-glutamate has no effect on the responsiveness of rabbit airways. ${ }^{19}$ In addition, guinea pig airways contain significantly greater amounts of substance $\mathrm{P}^{20}$ and are more sensitive to NK-1 and NK-2 receptors agonists than rabbit. $^{21}$ Capsaicin induces plasma extravasation in guinea pig and rat trachea ${ }^{22-24}$ but has no effect on rabbit trachea. ${ }^{25}$ Concerning tissue differences, the density and the type of tachykinin receptors, as well as the tissue responsiveness to sensory peptides, alter from proximal to distal airways. ${ }^{26,27}$ Considering these observations, L-glutamate receptors may exist on the sensory fibers of rabbit but their activation and the subsequent release of sensory peptides neither provoke direct contractions or enhance ACh release. Direct measurements are necessary to test this hypothesis.

The presence of the NMDA receptor subunit has also been demonstrated by immunocytochemistry in neurons of rat larynx and esophagus containing NO and vasoactive intestinal peptide (VIP) ${ }^{28}$ from which the inhibitory nerves supplying airway smooth muscle originate. ${ }^{29}$ The presence of a functional nonadrenergic non-cholinergic inhibitory (iNANC) system in rabbits has also been demonstrated, ${ }^{30,31}$ but this system seems not to use NO as a neurotransmitter. $^{32}$ The other neurotransmitter of the iNANC system (VIP) has been detected in rabbit airways. ${ }^{33,34}$ Although VIP exerts its effect via cAMP formation, ${ }^{35}$ prostaglandins $^{36}$ as well as epithelium $^{37,38}$ may be involved in its effect. The release of VIP in rabbit trachea stimulated by L-glutamate could be a reasonable explanation, while s-glutamate failed to induce contractions since VIP has also a modulatory effect on ACh release. ${ }^{39}$ 
Previous observations in mammalian peripheral tissues, ${ }^{7,40-42}$ as well as in airways, ${ }^{7}$ suggest the existence of non-classical glutamate receptors. Studies in the central nervous system have reported glutamate receptor subtypes composed of both kainic acid or AMPA and NMDA receptor subunits, ${ }^{43}$ or non-classical glutamate receptors blocked by both NMDA and non-NMDA antagonists. ${ }^{44}$ In this respect, we tested the effect of the main EAA receptor agonists NMDA, AMPA and kainic acid as well as the combination of the NMDA plus kainic acid. Our

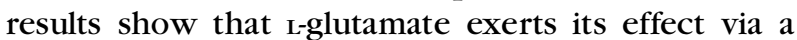
non-classical EAA receptor, since the classical EAA receptor agonists, NMDA, AMPA and kainic acid, were ineffective. However, the combination of NMDA + kainic acid decreased KCl-induced contractions. The role of $\mathrm{Mg}^{2+}$ was probably not significant in our system, as the presence or absence of $\mathrm{Mg}^{2+}$ did not affect the decrease of contraction evoked by kainic acid in the presence of NMDA in the bath medium. The effect of the combinations of EAA agonists tested in the present study was less potent than s-glutamate. Therefore, we cannot exclude the involvement of metabotropic receptors in this effect.

In conclusion, in rabbit trachea, L-glutamate in part has an epithelium-dependent effect, mediated via prostaglandin formation. The EAA receptors involved in this effect are non-classical EAA receptors of the NMDA/non-NMDA type.

\section{References}

1. Stevenson DD. Monosodium glutamate and asthma. J Nutr 2000; 130 : 1067S-1073S.

2. Said SI, Berisha HI, Pakbaz H. $N$-Methyl-D-aspartate receptors outside the central nervous system: activation causes acute lung injury that is mediated by nitric oxide synthesis and prevented by vasoactive intestinal peptide. Neuroscience 1995; 65: 943-946.

3. Said SI, Berisha HI, Pakbaz H. Excitotoxicity in the lung: $N$-methylD-aspartate-induced, nitric oxide-dependent, pulmonary edema is attenuated by vasoactive intestinal peptide and by inhibitors of poly(ADP-ribose) polymerase. Proc Natl Acad Sci USA 1996; 93: 4688-4692.

4. Said SI, Pakbaz H, Berisha HI, Raza SI. NMDA receptor activation: critical role in oxidant tissue injury. Free Radic Biol Med 2000; 28: 1300-1302.

5. Said SI. Glutamate receptors and asthmatic airway disease. Trends Pharmacol Sci 1999; 20: 132-134.

6. Said SI, Dickman KG. Pathways of inflammation and cell death in the lung: modulation by vasoactive intestinal peptide. Regulat Pept 2000; 93: 21-29.

7. Aas P, Tanso R, Fonnum F. Stimulation of peripheral cholinergic nerves by glutamate indicates a new peripheral glutamate receptor. Eur $J$ Pharmacol 1989; 164: 93-102.

8. Loenders B, Jorens PG, Herman AG. Epithelial modulation of cholinergic responses in rabbit trachea is partly due to neutral endopeptidase activity. Eur J Pharmacol 1996; 296: 89-96.

9. Martin W, Drazan KM, Newby AC. Methylene blue but not changes in cyclic GMP inhibits resting and bradykinin-stimulated production of prostacyclin by pig aortic endothelial cells. Br J Pharmacol 1989; 97 : 51-56.

10. Okamura T, Yoshida K, Toda N. Suppression by methylene blue of prostaglandin $\mathrm{I}_{2}$ synthesis in isolated dog renal arteries.J Pharmacol Exp Ther 1990; 254: 198-203.

11. Gao Y, Vanhoutte PM. Effects of hydrogen peroxide on the responsiveness of isolated canine bronchi: role of prostaglandin $\mathrm{E}_{2}$ and $\mathrm{I}_{2} . \mathrm{Am} \mathrm{J}$ Physiol 1992; 263: L402-L408.
12. Nasstrom J, Boo E, Stahlberg M, Berge OG. Tissue distribution of two NMDA receptor antagonists, $\left[{ }^{3} \mathrm{H}\right] \mathrm{CGS} 19755$ and $\left[{ }^{3} \mathrm{H}\right] \mathrm{MK}-801$, after intrathecal injection in mice. Pharmacol Biochem Behav 1993; 44 : 9-15.

13. Gill SS, Mueller RW, McGuire PF, Pulido OM. Potential target sites in peripheral tissues for excitatory neurotransmission and excitotoxicity. Toxicol Pathol 2000; 28: 277-284.

14. Cincotta M, Beart PM, Summers RJ, Lodge D. Bidirectional transport of NMDA receptor and ionophore in the vagus nerve. Eur J Pharmacol 1989; 160: 167-171.

15. Lewis SJ, Cincotta M, Verberne AJM, Jarrott B, Lodge D, Beart PM. Receptor autoradiography with $\left[{ }^{3} \mathrm{H}\right] \mathrm{L}$-glutamate reveals the presence and axonal transport of glutamate receptors in vagal afferent neurones of the rat. Eur J Pharmacol 1987; 144: 413-415.

16. Joos GF, Pauwels RA, van der Straeten ME. The mechanism of tachykinininduced bronchoconstriction in the rat. Am Rev Respir Dis 1988; 137 : 1038-1044

17. Stretton D, Belvisi MG, Barnes PJ. The effect of sensory nerve depletion on cholinergic neurotransmission in guinea pig airways. J Pharmacol Exp Ther 1992; 260: 1073-1080.

18. John C, Brunner S, Tanaka DT. Neuromodulation mediated by neurokinin1 subtype receptors in adult rabbit airways. Am J Physiol 1993; 265 : L228-L233.

19. Nicholson A, Phillips CL, Allen DH, Ward HE, Berend N. The effect of L-glutamic acid on airway function and reactivity in the rabbit. Agents Actions 1988; 25: 267-272.

20. Spina D, Matera GM, Riccio MM, Page CP. A comparison of sensory nerve function in human, guinea-pig, rabbit and marmoset airways. Life Sci 1998; 63: 1629-1642.

21. Yuan L, Burcher E, Nail BS. Characterization of tachykinin receptors mediating bronchomotor and vasodepressor responses to neuropeptide $\gamma$ and substance $P$ in the anaesthetized rabbit. Pulmon Pbarmacol Ther 1998; $11: 31-39$.

22. Tousignant C, Chan CC, Young D, Guevremont D, Rodger IW. Neurokinin receptor mediated plasma extravasation in guinea pig and rat airways: comparison of ${ }^{125} \mathrm{I}$-labelled human fibrinogen and $99 \mathrm{mTc}$-labelled human serum albumin as markers of leakage. Can J Pbysiol Pharmacol 1993; 71: 506-511.

23. Evangelista S, Paoli S, Giachetti A, Manzini S. Involvement of tachykinin NK1 receptors in plasma protein extravasation induced by tachykinins in the guinea pig upper airways. Neuropeptides 1997; 31: 65-70.

24. Auberson S, Lundberg JM. Lactic acid-induced plasma protein extravasation in rat airways by stimulation of sensory nerves and NK1 receptor activation. Pharmacol Toxicol 1993; 73: 305-310.

25. Matheson MJ, Rynell AC, McClean MA, Berend N. Tachykinins do not cause plasma leakage in the rabbit trachea. Respir Pbysiol 1997; 108: $165-170$.

26. Black J, Diment L, Armour C, Alouan L, Johnson P. Distribution of substance $P$ receptors in rabbit airways, functional and autoradiographic studies. J Pharmacol Exp Ther 1990; 253: 381-386.

27. Cook JA, Brunner SL, Tanaka DT. Neurokinin receptors mediating substance P-induced contraction in adult rabbit airways. Am J Pbysiol 1990; 258: L99-L106.

28. Robertson BS, Satterfield BE, Said SI, Dey RD. $N$-Methyl-D-aspartate receptors are expressed by intrinsic neurons of rat larynx and esophagus. Neurosci Lett 1998; 244: 77-80.

29. Canning BJ, Undem BJ, Karakousis PC, Dey RD. Effects of organotypic culture on parasympathetic innervation of guinea pig trachealis. Am J Physiol 1996; 271: L698-L706.

30. Colasurdo GN, Loader JE, Graves JP, Larsen GL. Maturation of nonadrenergic noncholinergic inhibitory system in normal and allergensensitized rabbits. Am J Physiol 1994; 267: L739-L744.

31. Fame TM, Colasurdo GN, Loader JE, Graves JP, Larsen GL. Decrease in the airways nonadrenergic noncholinergic inhibitory system in allergen sensitized rabbits. Pediatr Pulmonol 1994; 17: 296-303.

32. Fame TM, Loader JE, Graves JP, Colasurdo GN, Larsen GL. Decrease in the airways non-adrenergic non-cholinergic inhibitory system in allergen sensitized rabbits. Am Rev Respir Dis 1993; 147: A285.

33. Uddman R, Alumets J, Densert O, Hakanson R, Sundler F Occurrence and distribution of VIP nerves in the nasal mucosa and tracheobronchial wall. Acta Otolaryngol 1978; 86: 443-448.

34. Sakai N, Tamaoki J, Kobayashi K, Kanemura T, Isono K, Takeyama K, Takeuchi S, Takizawa T. Vasoactive intestinal peptide stimulates ciliary motility in rabbit tracheal epithelium: modulation by neutral endopeptidase. Regulat Pept 1991; 34: 33-41.

35. Said SI. Vasoactive intestinal peptide. In: Raeburn D, Giembycz MA, eds. Airways Smooth Muscle: Peptide Receptors, Ion Channels and Signal Transduction. Basel: Birkhäuser Verlag, 1995: 87-113.

36. Regal JF, Johnson DE. Indomethacin alters the effects of substance-P and VIP on isolated airway smooth muscle. Peptides 1983; 4: 581-584.

37. Farmer SG, Togo J. Effects of epithelium removal on relaxation of airway smooth muscle induced by vasoactive intestinal peptide and electrical field stimulation. Br J Pharmacol 1990; 100: 73-78.

38. Uzuner K, Tuncel N, Aydin Y. Relaxing effects of vasoactive intestinal peptide (VIP) on the contractile actions of endothelin-3, histamine, and acetylcholine in isolated guinea pig tracheal smooth muscle with or without epithelium. Peptides 1996; 17: 299-303. 
39. Colasurdo GN, Loader JE, Graves JP, Larsen GL. Modulation of acetylcholine release in rabbit airways in vitro. Am J Pbysiol 1995; 268: L432-L437.

40. Yoneda $\mathrm{Y}$, Ogita $\mathrm{K}$. Localization of $\left[{ }^{3} \mathrm{H}\right]$ glutamate binding sites in rat adrenal medulla. Brain Res 1986; 383: 387-391.

41. Yoneda Y, Ogita K. Enhancement of $\left[{ }^{3} \mathrm{H}\right]$ glutamate binding by $N$-methylD-aspartic acid in rat adrenal. Brain Res 1987; 406: 24-31.

42. Winter CR, Baker RC. L-Glutamate-induced changes in intracellular calcium oscillation frequency through non-classical glutamate receptor binding in cultured rat myocardial cells. Life Sci 1995; 57: 1925-1934.
43. Barnard EA. Ionotropic glutamate receptors: new types and new concepts. Trends Pharmacol Sci 1997; 18: 141-147.

44. Marin P, Quignard JF, Lafon-Cazal M, Bockaert J. Non-classical glutamate receptors, blocked by both NMDA and non-NMDA antagonists, stimulate nitric oxide production in neurons. Neuropharmacology 1993; 32: $29-36$.

\section{Received 24 July 2001}

Accepted 14 November 2001 


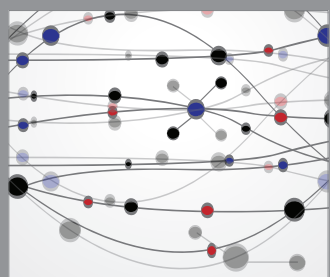

The Scientific World Journal
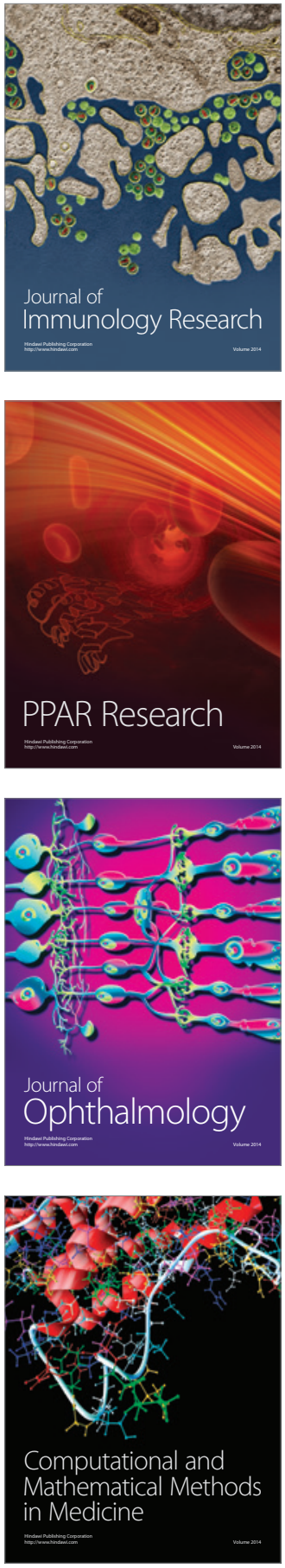

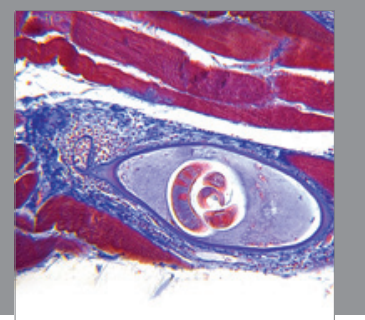

Gastroenterology

Research and Practice
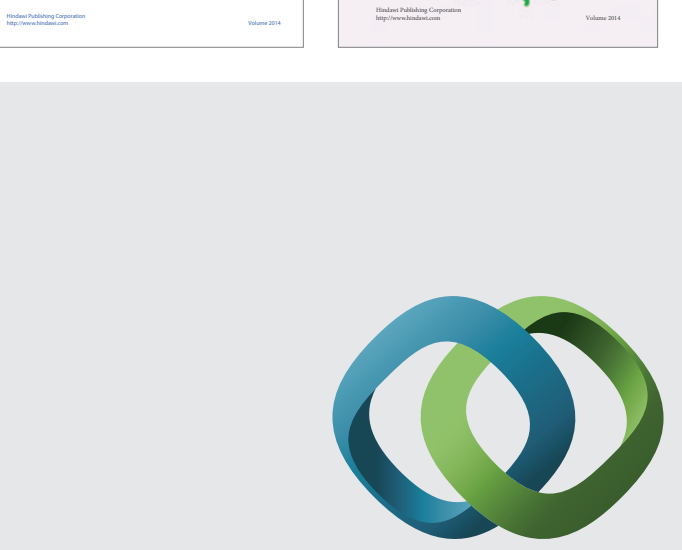

\section{Hindawi}

Submit your manuscripts at

http://www.hindawi.com
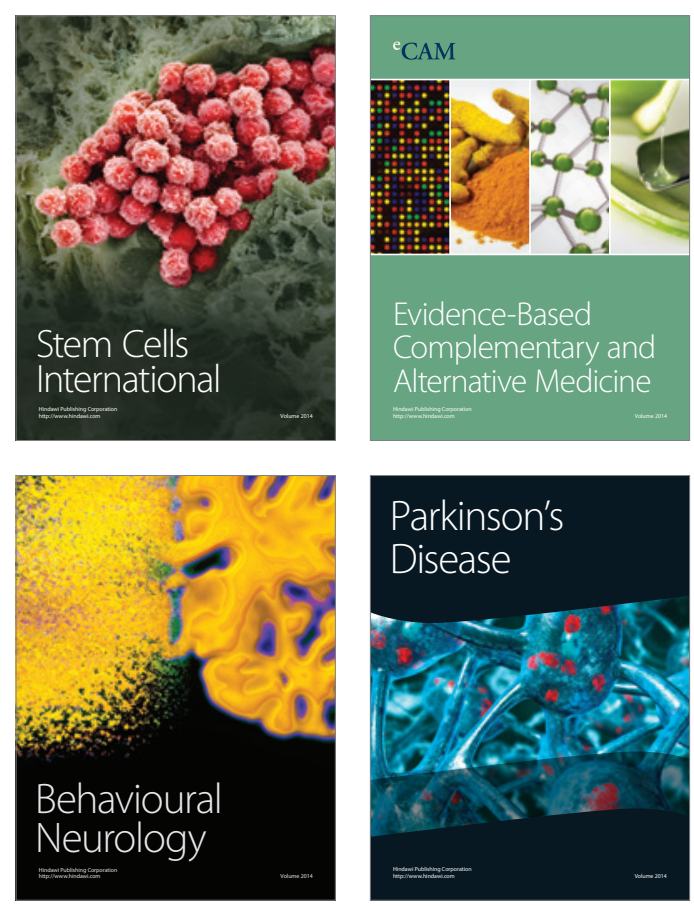

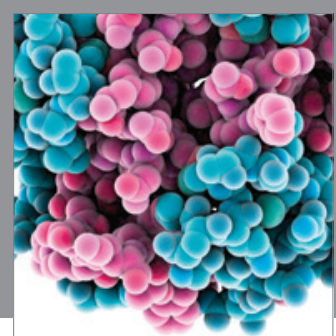

Journal of
Diabetes Research

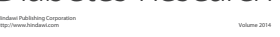

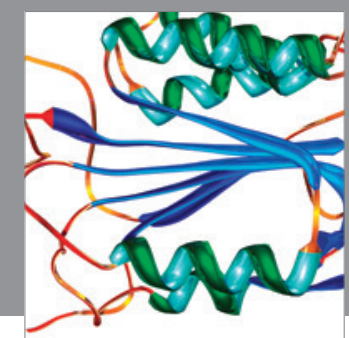

Disease Markers
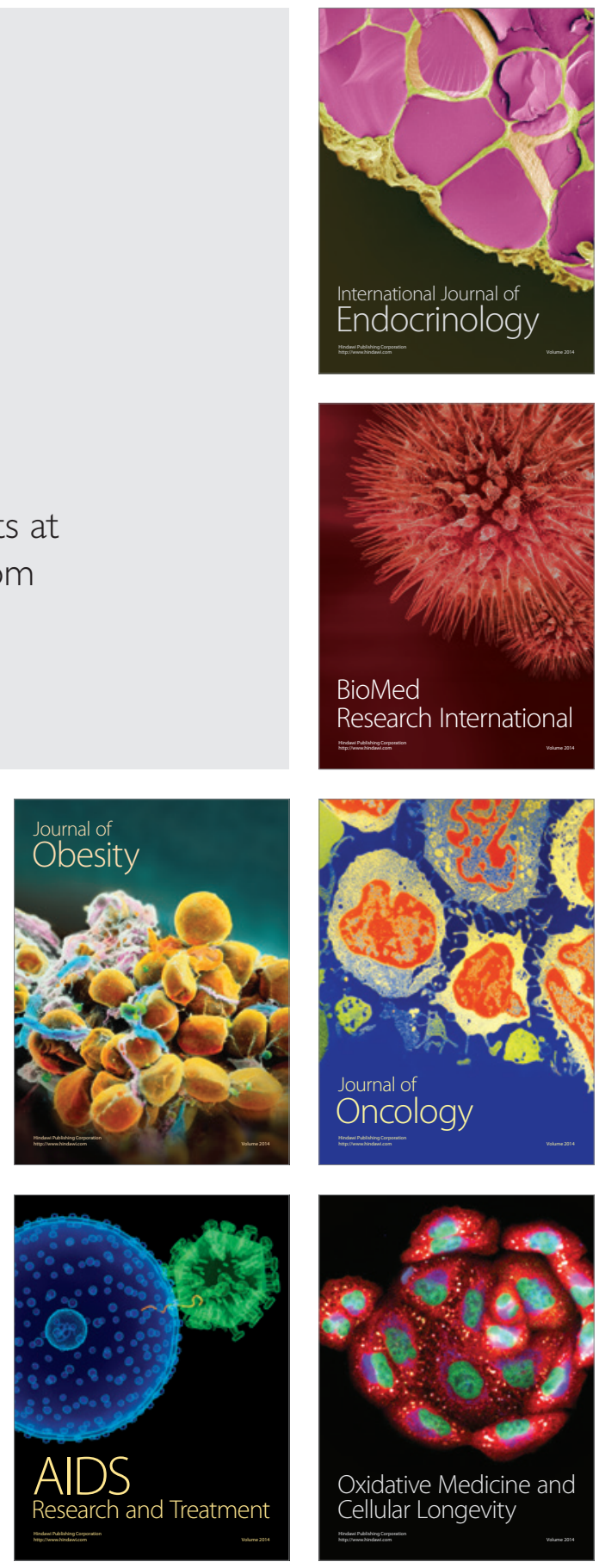